
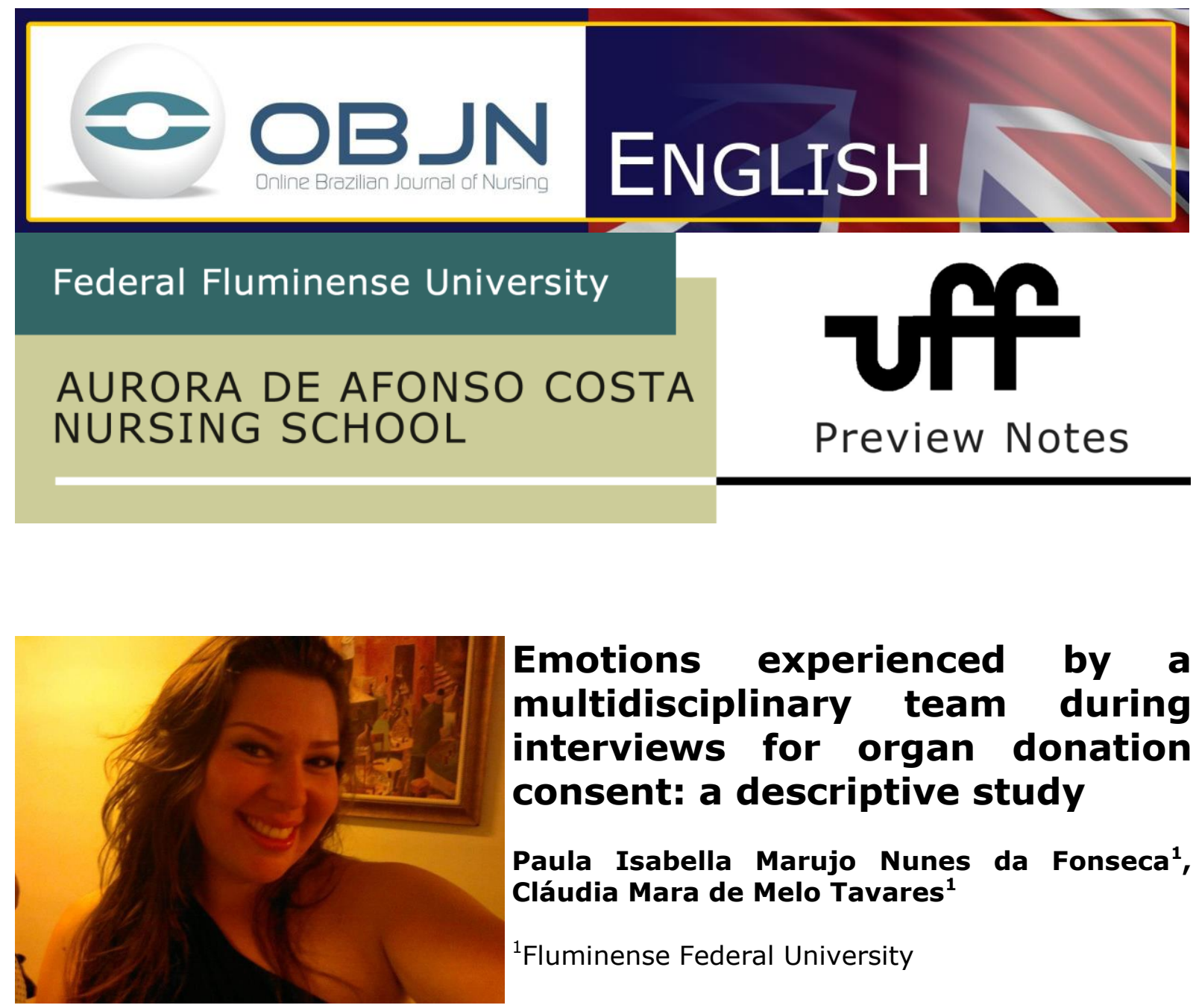

\title{
Emotions experienced by a multidisciplinary team during interviews for organ donation consent: a descriptive study
}

\author{
Paula Isabella Marujo Nunes da Fonseca ${ }^{1}$, \\ Cláudia Mara de Melo Tavares ${ }^{1}$ \\ ${ }^{1}$ Fluminense Federal University
}

\begin{abstract}
This is a study on the emotions experienced during family interviews for organ donation consent by a multidisciplinary team of the Transplant Centre in the state of Rio de Janeiro. It focuses on the emotion management strategies used by these professionals. Aims: To identify the emotions experienced by healthcare professionals during family interviews for organ donation consent; to describe the management of the emotions experienced by these professionals during family interviews; and to indicate measures to promote emotional education among the professional interviewers. Method: This is a qualitative descriptive study. The participants are nurses, social workers, psychologists and doctors who conduct/have conducted family interviews. The methodology will use an instrument for socioeconomic characterization, a questionnaire with eight core questions on the emotions experienced during family interviews and their management, and the Active Imagination technique proposed by Jung. The project has been approved by Ethics and Research of the University Hospital Antonio Pedro, under No. 321/1.
\end{abstract}

Keywords: Expressed Emotion; Health Personnel; Interview; Transplants. 


\section{SITUATION PROBLEM AND ITS SIGNIFICANCE}

Donation and organ transplantation are complex processes that involve identification and maintenance of a potential donor; tests to evaluate and determine brain death through clinical, neurological and graphic examination; communicating diagnosis to relatives; conducting family interviews for donation consent; and in the case of consent, conducting the processes of capturing and distributing organs.

Family interview is defined as a meeting between potential donors' families and one or more members of the transplant team, or other trained professionals, for obtaining consent for donation, and is highlighted in this study due to the emotional/subjective complexity it bears ${ }^{(1)}$. Therefore, professionals who conduct family interviews should be well prepared for presenting an appropriate technical and emotional approach.

However, the multidisciplinary team of the Transplant Centre that has been observed is not aware of such emotions. This unawareness, combined with a lack of emotional support and attention towards these professionals' mental health, is the main problem of this study.

In this context, the concept of emotional education will be dealt with since emotional issues do happen and it is well recognized that awareness and an ability to manage one's own emotions is the best indicator of success ${ }^{(2)}$. It is noteworthy that healthcare and education have gone through such a transformation process that it inevitably leads to a historical reflection on these areas so as to construct new realities ${ }^{(3)}$.

\section{GUIDING QUESTIONS}

What emotions are experienced by professionals who conduct family interviews for organ and tissue donation? How do the professionals who conduct family interviews manage the emotions experienced during this process? What elements can be used to assess the level of emotional education among healthcare professionals? 


\section{AIMS}

The general aim is to understand the emotions experienced by a multidisciplinary team of the Transplant Centre during family interviews for organ donation, focusing on the emotion management strategies used by these professionals. The specific objectives are to identify the emotions experienced by healthcare professionals during family interviews for organ donation, describe the management of such emotions by these professionals, and to indicate measures to promote emotional education among the professional interviewers.

\section{METHOD}

This study uses a descriptive qualitative approach and is based on Jean Watson's Theory of Transpersonal Caring and on the concepts of Emotional Intelligence and Emotional Education. The study setting is the Transplant Centre in the state of Rio de Janeiro. Participants include seventeen female nurses, two female social workers, three female psychologists and two doctors of both sexes, who work or have previously worked as family interviewers for organ donation consent. The percentages represented by these participants in relation to the total number of professionals from each category who conduct family interviews at the Transplant Centre studied are 81 percent for nurses, 100 percent for social workers, 100 percent for psychologists and 40 percent for doctors. This study has excluded those professionals who do not or have never conducted family interviews, and also those who are no longer members of the Centre's transplant team. Data collection, which is now under development, will occur in three distinct stages, as follows: 1) signing on consent forms; 2) completing the questionnaire for socio-cultural characterization that contains fifteen items, followed by a semi-structured interview with nine questions that aim to identify emotions and their management during family interviews; and 3) to conclude, the Active Imagination technique proposed by Jung will be applied. This consists of listening to music with closed eyes for about three minutes. 
Subsequently, the researcher will ask the participants the following question: "When I talk about emotions in family interviews, which image comes to your mind?" The participants will be asked to answer the question by drawing the images with crayons on white A4 paper. Written words will not be used in this stage. The interviews will be recorded in an electronic device and will gradually be transcribed for later analysis. This project has been approved by the Ethics Committee of Antonio Pedro University Hospital, under No. 321/11, CAAE: 0336.0.258.000-11, thus respecting the ethical principles for research involving human participants, as provided in Resolution No. 196 / 96. Data analysis will be performed by content analysis.

\section{REFERENCES}

1. Santos MJ. A entrevista familiar no processo de doação de órgãos e tecidos para transplante. Tese [Doutorado em enfermagem]. Ribeirão Preto: Universidade de São Paulo; 2010.

2. Casassus J. Fundamentos da educação emocional. Brasília: UNESCO; 2009.

3. Aarestrup C, Tavares CMM. A gestão do sistema de saúde e a formação do enfermeiro: pesquisa exploratória de campo. Online braz $\mathrm{j}$ nurs [serial in the internet]. 2007 [cited 2012 may 06]; 6(1). Available from: http://www.objnursing.uff.br/index.php/nursing/article/view/862/179

Project details: Dissertation Research Project of the Science in Healthcare Master's Program.

Approved by UFF's Ethics Committee in Research: No. 321/11, CAAE: 0336.0.258.000-11.

Financial Support: Master's scholarship granted by REUNI.

Mail Address: Estrada Campo de Areia, 56. Apt 301, Pechincha - Rio de Janeiro / RJ. CEP: 22743-310. Email address: paulaisabellafonseca@yahoo.com.br paulaisabellafonseca@yahoo.com.br 